\title{
Copy number variation at leptin receptor gene locus associated with metabolic traits and the risk of type 2 diabetes mellitus
}

\author{
Jae-Pil Jeon*+1, Sung-Mi Shim¹', Hye-Young Nam¹, Gil-Mi Ryu², Eun-Jung Hong ${ }^{1}$, Hyung-Lae Kim² and Bok- \\ Ghee Han*1
}

\begin{abstract}
Background: Recent efforts have been made to link complex human traits and disease susceptibility to DNA copy numbers. The leptin receptor (LEPR) has been implicated in obesity and diabetes. Mutations and genetic variations of LEPR gene have been discovered in rodents and humans. However, the association of DNA copy number variations at the LEPR gene locus with human complex diseases has not been reported. In an attempt to study DNA copy number variations associated with metabolic traits and type 2 diabetes mellitus (T2DM), we targeted the LEPR gene locus in DNA copy number analyses.

Results: We identified DNA copy number variations at the LEPR gene locus among a Korean population using genome-wide SNP chip data, and then quantified copy numbers of the E2 DNA sequence in the first two exons overlapped between LEPR and LEPROT genes by the quantitative multiplex PCR of short fluorescent fragment (QMPSF) method. Among the non-diabetic subjects $(n=1,067)$, lower E2 DNA copy numbers were associated with higher fasting glucose levels in men $\left(p=1.24 \times 10^{-7}\right)$ and women $\left(p=9.45 \times 10^{-5}\right)$, as well as higher total cholesterol levels in men $\left(p=9.96 \times 10^{-7}\right)$. In addition, the significant association between lower E2 DNA copy numbers and lower level of postprandial $2 \mathrm{hr}$ insulin was evident only in non-diabetic women, whereas some obesity-related phenotypes and total cholesterol level exhibited significant associations only in non-diabetic men. Logistic regression analysis indicated that lower E2 DNA copy numbers were associated with T2DM (odds ratio, 1.92; 95\% Cl, 1.26 2.96; $\mathrm{p}<0.003$ ) in our nested case-control study. Interestingly, the E2 DNA copy number exhibited a negative correlation with LEPR gene expression, but a positive correlation with LEPROT gene expression.
\end{abstract}

Conclusions: This work suggests that a structural variation at the LEPR gene locus is functionally associated with complex metabolic traits and the risk of T2DM.

\section{Background}

Leptin and the leptin receptor (LEPR) are involved in satiety and energy expenditure via central and peripheral mechanisms. The primary site of leptin action is the hypothalamus where the leptin receptor interacts with the adipocyte-derived leptin signal to regulate appetite, energy balance, and metabolism. LEPRs also regulate energy homeostasis in peripheral tissues including skele-

\section{* Correspondence: jaepiljeon@hanmail.net, bokghee@yahoo.com}

Division of Biobank for Health Sciences, Korea National Institute of Health, Korea Centers for Disease Control and Prevention, 194 Tongil Ro, Seoul, 122-

701, Korea

+ Contributed equally

Full list of author information is available at the end of the article tal muscle, liver, pancreas, and adipose tissue. Leptin prevents obesity via LEPRs by stimulating glucose uptake and fatty acid oxidation in skeletal muscle and liver [1-3], and inhibits insulin secretion of pancreatic $\beta$-cells [4].

Mutations and genetic variations of the $L E P R$ gene have been discovered in rodents and humans. Sequencingbased detection of LEPR mutations demonstrated that frame-shift or missense mutations of the LEPR gene caused obesity, pituitary dysfunction, hyperphagia, or hypogonadism in humans [5,6]. In rodents, leptin receptor gene mutations resulted in obesity, hyperglycemia, hyperinsulinemia, and reduced fertility $[7,8]$. Common genetic variants (e.g., SNPs) at the LEPR gene locus have

( 2010 Jeon et al; licensee BioMed Central Ltd. This is an Open Access article distributed under the terms of the Creative Commons BHoWed Central Attribution License (http://creativecommons.org/licenses/by/2.0), which permits unrestricted use, distribution, and reproduction in any medium, provided the original work is properly cited. 
been associated with obesity, hyperinsulinemia, type 2 diabetes mellitus (T2DM), and variations in leptin levels in different populations. For example, three non-synonymous SNPs (Arg109Lys, Arg223Gln, and Lys656Asn) have been evaluated for association studies [9-13]. Therefore, most association studies of $L E P R$ polymorphisms have been performed on SNPs or deletion/insertion polymorphisms (DIPs). However, the association of DNA copy number variations (CNVs) at the LEPR gene locus with human diseases has not yet been reported.

In recent years, comprehensive human CNV maps were assembled using various experimental platforms [14-16]. While the growing number of genome-wide association data sets can be utilized to detect clinically-relevant CNVs, absolute copy number information cannot be easily determined by current quantitative assays, with the exception of Fiber-FISH. Nonetheless, recent studies have shown that CNVs are implicated in human diseases including glomerulonephritis (FCGR3B) [17], HIV-1/ AIDS (CCL3L1) [18], bipolar disorder and schizophrenia (GLUR7, CACNG2 and AKAP5) [19], neoplasia (14q12) [20], psoriasis (DEFB) [21], and myocardial infarction (C4B) [22].

\section{Results}

On employing a candidate gene approach to the association study of CNVs with diabetes and metabolic traits, we targeted the genomic locus of the LEPR gene encompassing approximately $200 \mathrm{~kb}$ of chromosome 1 . DNA copy number analysis of the Affymetrix $50 \mathrm{~K}$ SNP array data showed that the Korean population exhibited CNVs at the LEPR gene locus (Additional file 1). Our QMPSF experiments generated continuous variables of DNA copy number at the LEPR locus for individuals (Additional file 2). Next, the experimental copy number information was transformed to dichotomized DNA copy numbers (low or high) for CNV association studies. An appropriate copy number value (low or high) was then assigned to each individual using either male or female median copy number value among non-diabetic subjects ( $\mathrm{n}=1,067)$ as the cutoff. The same cutoff value was used to dichotomize copy numbers among diabetes subjects in the nested case-control study. DNA copy numbers were determined using only a short PCR fragment (herein referred to the "E2 DNA", located near exon 2 of the LEPR gene, see Figure 1) of the entire LEPR gene sequence. To address the question as to whether this short sequence was representative of the whole LEPR gene, we investigated the CNV boundaries using PCR-based (QMPSF) and array-based (Affymetrix SNP array 5.0) analyses. Relative DNA copy numbers were obtained by QMPSF using primers targeting several regions along the LEPR gene sequence. QMPSF results showed that the copy number of the E2 DNA sequence was correlated to that of the promoter-containing exon region at the LEPR locus, but not to the other downstream exonic regions (Figure 1). On the other hand, CNV analysis of the Affymetrix SNP array 5.0 data revealed that the whole LEPR gene locus region was highly $\mathrm{CNV}$-affected, with a varied length of CNV boundaries over the LEPR gene sequence (Additional file 1). This result indicated that the E2 DNA copy number did not represent DNA copy numbers of the whole LEPR gene, but a partial DNA sequence containing the LEPROT (leptin receptor overlapping transcript) gene at the LEPR locus.

Next, we tested the statistical significance of the association of the E2 DNA copy number with metabolic traits. In male non-diabetic subjects, significant differences for some demographic characteristics were observed between low (1X) and high (2X) copy number individuals (Table 1). Fasting glucose and total cholesterol levels were higher in individuals with low copy numbers of the E2 DNA at LEPR gene locus in three different age groups of male individuals (Figure 2). The association of low copy numbers with higher levels of obesity-related phenotypes and total cholesterol levels remained significant in linear regression analysis with age-and BMI-adjustments followed by Bonferroni correction for multiple testing among male individuals (Table 1). Among female subjects, E2 DNA copy numbers were also associated with levels of fasting glucose and postprandial $2 \mathrm{hr}$ insulin. On the other hand, beneficial phenotypes for obesity-related traits and total cholesterol levels were associated with higher DNA copy numbers $(2 \mathrm{X})$ of the LEPR gene locus in male subjects.

The copy numbers of the E2 DNA sequence at the LEPR gene locus were used in the nested case-control study of T2DM, in which subjects $(\mathrm{n}=137)$ were matched for age, sex, and BMI at a ratio of approximately $1: 2$ to control subjects $(n=258)$. Our case groups showed typical demographic characteristics to diabetes subjects (Additional file 3). For example, diabetic case subjects had higher triglyceride, higher total cholesterol, and lower HDL-cholesterol than those levels in non-diabetic subjects. Logistic regression analysis showed that low E2 DNA copy numbers were associated with T2DM (odds ratio, 1.92; 95\% CI, 1.26 2.96), with a significance of $\mathrm{P}<$ 0.003 (Table 2).

To study biological roles of the E2 DNA copy numbers, we compared mRNA expression levels of both LEPR and LEPROT genes with E2 DNA copy numbers in lymphoblastoid cell lines. The E2 DNA sequence exists immediately downstream of the overlapped exon 2 of the LEPR and LEPROT genes. Real-time PCR analysis showed a significant negative correlation of the E2 DNA copy number with the LEPR transcript level $(\mathrm{R} 2=0.439, \mathrm{p}=1.52 \times$ 10-4), but a weak positive correlation with the LEPROT transcript level $(\mathrm{R} 2=0.135, \mathrm{p}<0.05)$ (Figure 3$)$. More- 


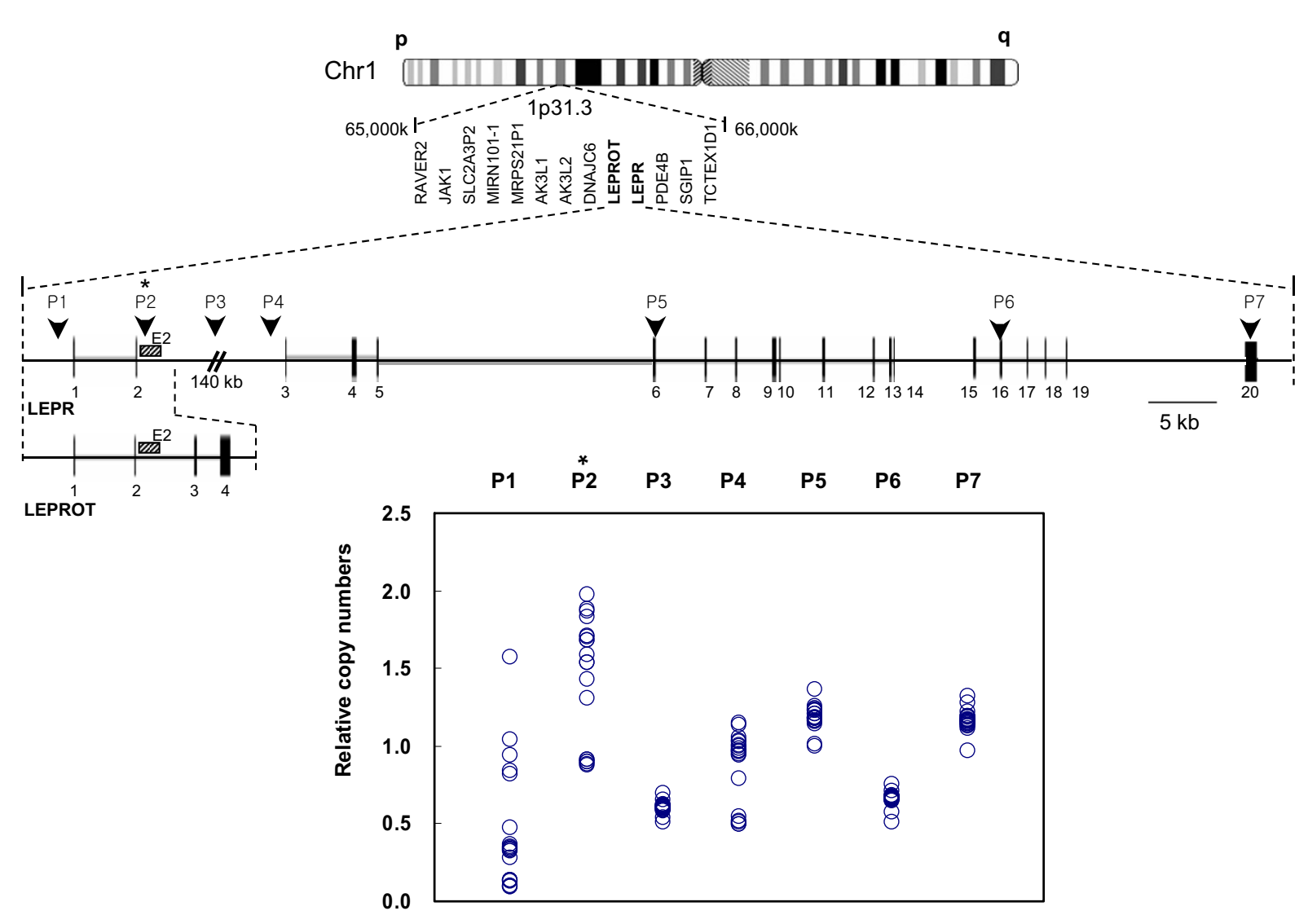

Figure 1 Schematic diagram of CNVs at the LEPR gene locus. Genomic structures of LEPR and LEPROT genes, including exons, are shown. E2 DNA content relative to the Factor VIII gene from 20 subjects is displayed in the lower panel. Primer target sites (P1 to P7) for QMPSF are indicated along the LEPR sequence. $P 2^{*}$ indicates the primer target site for detection of the initial copy number at the LEPR locus. P1 and P2 primer target sites were highly variable for copy number among the 19 individuals tested, but the other primer sites were not.

over, the LEPR expression level was inversely correlated with the LEPROT expression level $(\mathrm{R} 2=0.126, \mathrm{p}<0.05)$. This result suggests that higher copy numbers of the E2 DNA may contribute to higher transcriptional activity of the LEPROT gene by gene dosage effect, which may be accordingly responsible for downregulation of LEPR gene.

\section{Discussion}

Our candidate gene approach to CNV association studies identified the E2 DNA copy number variation at the LEPR gene locus, which was associated with metabolic traits and the risk of T2DM. Lower copy numbers of the E2 DNA were associated with higher fasting glucose in both male and female non-diabetic subjects. However, obesity-related traits and total cholesterol levels exhibited significant association with the E2 DNA copy numbers only in male non-T2DM subjects whereas postprandial $2 \mathrm{hr}$ insulin level was significantly higher only in female non-T2DM subjects. These results suggest that the E2 DNA copy number variations at the LEPR gene locus may contribute to glucose homeostasis and energy metabolism in a different manner between male and female subjects.

In our CNV association study, we observed that the beneficial high E2 DNA copy number was associated with lower fasting glucose levels (hypoglycemia) in both genders which are beneficial in terms of diabetes. Similar results were reported for mouse models with LEPR signaling defects [23,24]. For example, hypothalamus and pancreas-specific LEPR signaling disruption led to fasting hypoglycemia, hyperinsulinemia, and hypertriglyceridemia, highlighting the important role of beta cells in LEPR mediated glucose homeostasis [24]. Hypothalamic LEPR KOVMH mice fed a low fat diet also exhibited hypertriglyceridemia without concomitant hypercholesterolemia [25]. Neuronal LEPR deletion induces diabetic phenotypes such as body weight increase, adiposity, and hyperglycemia in proportion to hypothalamic LEPR deficiency [25]. In addition, antisense-RNA mediated adipocyte-specific reduction of LEPR leads to decrease in LEPR signaling, resulting in increased adipocyte, hyper- 
Table 1: Association of LEPR CNVs with metabolic traits in nondiabetic subjects.

\begin{tabular}{|c|c|c|c|c|c|c|c|c|c|c|}
\hline \multirow[t]{2}{*}{ Variables } & \multicolumn{3}{|c|}{ Men $(n=574)$} & \multicolumn{7}{|c|}{ Women $(n=493)$} \\
\hline & $\begin{array}{l}\text { Low CN (1X) } \\
(n=287)\end{array}$ & $\begin{array}{l}\text { High CN (2X) } \\
\quad(n=287)\end{array}$ & Pvalue* & $\begin{array}{r}P \text { value** } \\
\text { (adjusted) }\end{array}$ & $\begin{array}{l}\text { Pvalue*** } \\
\text { (corrected) }\end{array}$ & $\begin{array}{l}\text { Low CN (1X) } \\
\quad(n=246)\end{array}$ & $\begin{array}{l}\text { High CN (2X) } \\
\quad(n=247)\end{array}$ & Pvalue* & $\begin{array}{r}P \text { value** } \\
\text { (adjusted) }\end{array}$ & $\begin{array}{l}\text { Pvalue**** } \\
\text { (corrected) }\end{array}$ \\
\hline Age (year) & $49.1 \pm 8.4$ & $50.7 \pm 8.6$ & 0.026 & - & - & $52.9 \pm 9.0$ & $52.5 \pm 8.6$ & 0.505 & - & - \\
\hline Height $(\mathrm{cm})$ & $167.2 \pm 5.7$ & $167.6 \pm 6.1$ & 0.479 & 0.074 & ns & $153.9 \pm 5.9$ & $153.7 \pm 5.6$ & 0.887 & 0.716 & ns \\
\hline Weight (kg) & $67.1 \pm 9.4$ & $66.6 \pm 9.4$ & 0.431 & 0.082 & ns & $57.3 \pm 8.6$ & $57.6 \pm 7.7$ & 0.814 & 0.690 & ns \\
\hline Pulse (counts) & $61.0 \pm 6.5$ & $61.4 \pm 7.2$ & 0.418 & 0.439 & ns & $64.2 \pm 7.1$ & $63.8 \pm 6.8$ & 0.656 & 0.719 & ns \\
\hline Systolic blood pressure $(\mathrm{mmHg})$ & $114.0 \pm 14.7$ & $114.6 \pm 13.9$ & 0.575 & 0.776 & ns & $115.5 \pm 17.6$ & $115.8 \pm 15.7$ & 0.800 & 0.608 & ns \\
\hline Diastolic blood pressure $(\mathrm{mmHg})$ & $75.1 \pm 11.2$ & $74.5 \pm 10.6$ & 0.512 & 0.502 & ns & $72.7 \pm 11.1$ & $73.4 \pm 10.0$ & 0.401 & 0.286 & ns \\
\hline Distal radius Z & $0.16 \pm 1.23$ & $0.48 \pm 1.35$ & $2.85 \mathrm{E}-03$ & 0.013 & ns & $0.91 \pm 1.48$ & $1.08 \pm 1.53$ & 0.305 & 0.295 & ns \\
\hline Midshaft tibia Z & $0.47 \pm 1.06$ & $0.68 \pm 1.18$ & 0.025 & 0.071 & ns & $-0.36 \pm 1.30$ & $-0.39 \pm 1.31$ & 0.768 & 0.834 & ns \\
\hline Waist circumference $(\mathrm{cm})$ & $82.2 \pm 7.3$ & $81.4 \pm 7.1$ & 0.194 & 0.353 & ns & $81.0 \pm 9.3$ & $81.7 \pm 9.2$ & 0.531 & 0.311 & ns \\
\hline Hip circumferences (cm) & $93.9 \pm 5.6$ & $92.2 \pm 6.2$ & $3.67 \mathrm{E}-04$ & $6.07 \mathrm{E}-04$ & $1.76 \mathrm{E}-02$ & $91.9 \pm 6.3$ & $91.7 \pm 6.0$ & 0.849 & 0.455 & ns \\
\hline Waist-to-hip ratio (WHR) & $0.88 \pm 0.06$ & $0.88 \pm 0.06$ & 0.080 & 0.074 & ns & $0.88 \pm 0.08$ & $0.89 \pm 0.08$ & 0.380 & 0.182 & ns \\
\hline Body fat (\%) & $20.5 \pm 4.9$ & $19.4 \pm 4.5$ & $6.01 \mathrm{E}-03$ & $1.03 \mathrm{E}-03$ & 2.99E-02 & $29.6 \pm 5.8$ & $30.3 \pm 4.8$ & 0.201 & 0.072 & ns \\
\hline Visceral fat (\%) & $0.89 \pm 0.04$ & $0.88 \pm 0.04$ & $9.45 \mathrm{E}-03$ & $1.02 \mathrm{E}-06$ & 2.95E-05 & $0.89 \pm 0.05$ & $0.89 \pm 0.05$ & 0.898 & 0.814 & ns \\
\hline Obesity degree (\%) & $112.2 \pm 12.7$ & $110.2 \pm 12.5$ & 0.051 & $5.85 \mathrm{E}-04$ & $1.70 \mathrm{E}-02$ & $119.9 \pm 17.2$ & $120.8 \pm 15.1$ & 0.686 & 0.643 & ns \\
\hline Body mass index (BMI) $\left(\mathrm{kg} / \mathrm{m}^{2}\right)$ & $23.9 \pm 2.7$ & $23.6 \pm 2.7$ & 0.158 & - & - & $24.2 \pm 3.3$ & $24.4 \pm 2.9$ & 0.715 & - & - \\
\hline Total cholesterol (mg/dL) & $199.1 \pm 36.7$ & $181.7 \pm 32.8$ & $3.23 \mathrm{E}-09$ & $3.43 \mathrm{E}-08$ & 9.96E-07 & $188.0 \pm 34.3$ & $180.9 \pm 31.0$ & $2.25 \mathrm{E}-02$ & $2.50 \mathrm{E}-02$ & ns \\
\hline HDL-cholesterol (mg/dL) & $45.6 \pm 8.5$ & $44.4 \pm 9.5$ & 0.119 & 0.056 & ns & $47.7 \pm 9.9$ & $45.1 \pm 9.5$ & $7.40 \mathrm{E}-03$ & $5.51 \mathrm{E}-03$ & ns \\
\hline Triglyceride (mg/dL) & $146.9 \pm 86.1$ & $151.4 \pm 82.5$ & 0.521 & 0.323 & ns & $122.0 \pm 68.7$ & $137.1 \pm 73.2$ & 0.016 & $9.11 \mathrm{E}-03$ & ns \\
\hline C-reactive protein (mg/dL) & $0.19 \pm 0.31$ & $0.20 \pm 0.21$ & 0.601 & 0.593 & ns & $0.15 \pm 0.24$ & $0.21 \pm 0.52$ & 0.232 & 0.220 & ns \\
\hline WBC $\left(10^{3} / \mu \mathrm{L}\right)$ & $6.6 \pm 1.7$ & $6.4 \pm 1.7$ & 0.333 & 0.499 & ns & $5.8 \pm 1.5$ & $5.6 \pm 1.4$ & 0.099 & 0.083 & ns \\
\hline $\mathrm{RBC}\left(10^{6} / \mu \mathrm{L}\right)$ & $4.8 \pm 0.4$ & $4.7 \pm 0.4$ & $3.03 \mathrm{E}-03$ & 0.029 & ns & $4.1 \pm 0.3$ & $4.1 \pm 0.3$ & 0.350 & 0.322 & ns \\
\hline Hemoglobin $(\mathrm{g} / \mathrm{dL})$ & $14.7 \pm 1.0$ & $14.6 \pm 1.1$ & 0.191 & 0.552 & ns & $12.5 \pm 1.3$ & $12.4 \pm 1.1$ & 0.677 & 0.686 & ns \\
\hline Hemocritat & $44.4 \pm 3.2$ & $44.1 \pm 3.4$ & 0.158 & 0.456 & ns & $37.9 \pm 3.4$ & $37.7 \pm 3.5$ & 0.348 & 0.357 & ns \\
\hline $\mathrm{HbA1C}(\%)$ & $5.5 \pm 0.3$ & $5.5 \pm 0.3$ & 0.853 & 0.584 & ns & $5.5 \pm 0.3$ & $5.4 \pm 0.3$ & 0.409 & 0.495 & ns \\
\hline Insulin_Ohr ( $\mu \mathrm{lU} / \mathrm{ml})$ & $6.5 \pm 4.7$ & $6.2 \pm 2.6$ & 0.283 & 0.474 & ns & $7.6 \pm 5.1$ & $7.8 \pm 3.5$ & 0.644 & 0.066 & ns \\
\hline Insulin_1hr $(\mu \mathrm{lU} / \mathrm{ml})$ & $32.0 \pm 27.2$ & $34.5 \pm 33.2$ & 0.324 & 0.195 & ns & $29.5 \pm 26.9$ & $37.2 \pm 34.1$ & $6.66 \mathrm{E}-03$ & $5.38 \mathrm{E}-03$ & ns \\
\hline Insulin_2hr ( $\mu \mathrm{lU} / \mathrm{ml})$ & $18.9 \pm 18.2$ & $18.9 \pm 19.1$ & 0.994 & 0.713 & ns & $22.1 \pm 19.8$ & $29.1 \pm 24.0$ & $8.55 \mathrm{E}-04$ & 7.93E-04 & $2.30 \mathrm{E}-02$ \\
\hline
\end{tabular}


Table 1: Association of LEPR CNVs with metabolic traits in nondiabetic subjects. (Continued)

\begin{tabular}{|c|c|c|c|c|c|c|c|c|c|c|}
\hline Glucose_0hr (mg/dL) & $84.0 \pm 7.5$ & $80.3 \pm 6.5$ & $3.34 \mathrm{E}-10$ & $4.26 \mathrm{E}-09$ & 1.24E-07 & $80.7 \pm 6.7$ & $77.9 \pm 5.2$ & 3.37E-06 & $3.26 \mathrm{E}-06$ & 9.45E-05 \\
\hline Glucose_1 $\mathrm{hr}(\mathrm{mg} / \mathrm{dL})$ & $127.4 \pm 34.9$ & $128.3 \pm 36.8$ & 0.741 & 0.983 & ns & $121.7 \pm 34.9$ & $121.1 \pm 31.4$ & 0.675 & 0.754 & ns \\
\hline Glucose_2hr (mg/dL) & $94.9 \pm 21.4$ & $91.1 \pm 20.6$ & 0.030 & 0.037 & ns & $103.0 \pm 18.9$ & $101.3 \pm 18.9$ & 0.200 & 0.200 & ns \\
\hline HOMA-IR & $1.41 \pm 1.09$ & $1.39 \pm 0.59$ & 0.835 & 0.928 & ns & $1.70 \pm 1.15$ & $1.8 \pm 0.8$ & 0.261 & 0.263 & $\mathrm{~ns}$ \\
\hline
\end{tabular}

*: P value: t-test

**: P value: age-, BMI-adjusted linear regression test ( $\mathrm{CN}$ values)

***: $P$ value: obtained by Bonferroni correction for multiple testing. $n$ s indicates none-significance (cutoff $\mathrm{p}<0.05$ ). 
A

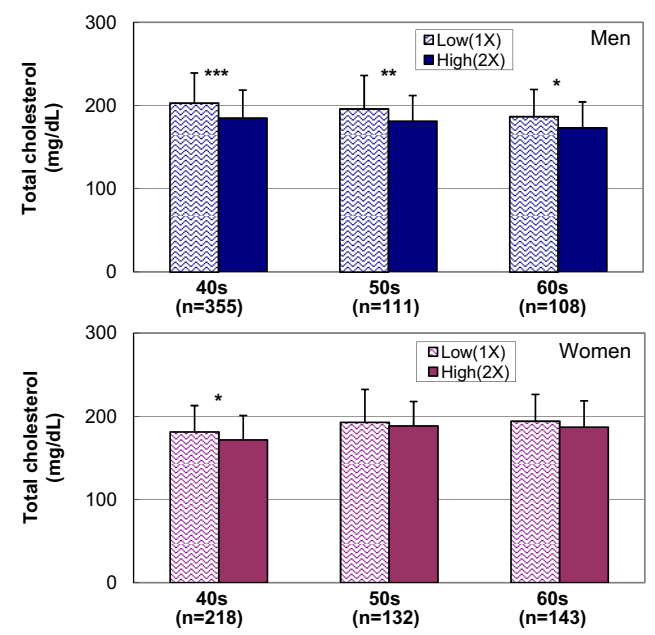

B
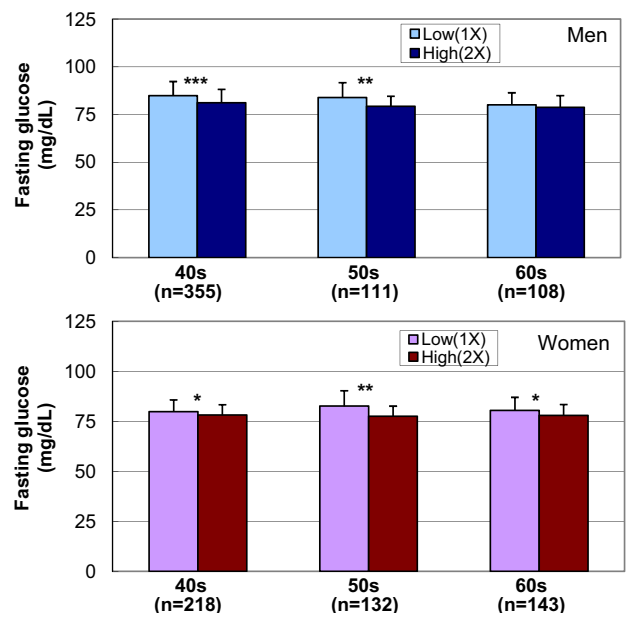

Figure 2 Total cholesterol and fasting glucose levels for individuals with low or high copy numbers of the E2 DNA sequence. NonT2DM subjects were divided into different age groups ( $40 \mathrm{~s}, 50 \mathrm{~s}$, and $60 \mathrm{~s}$ ) and their metabolic phenotypes were compared. (A) Total cholesterol levels. ${ }^{* * *}: P=2.13 \times 10^{-6},{ }^{* *}: P=4.33 \times 10^{-3}, *: P<0.05$. (B) Fasting glucose levels. ${ }^{* *}: P=1.72 \times 10^{-6},{ }^{* *}: P=8.39 \times 10^{-4}, *: P<0.03$.

triglyceridemia, and insulin resistance [26]. As presented in our association study, the high E2 copy number individuals shared similar phenotypes with LEPR deficient animal models. Moreover, human LEPR signaling mutations also caused obesity as well as impairments of pubertal development and growth hormone secretion [5]. Thus, it is conceivable that higher E2 DNA copy numbers may result in a decrease in LEPR signaling, which functions in a complex manner in different tissues.

Indeed, our expression analysis of LEPR gene in LCLs showed that the high E2 DNA copy number was significantly correlated with downregulation of the LEPR gene and concomitant upregulation of the LEPROT gene. Hypothalamic LEPR mRNA expression is indicative of functional LEP-LEPR signaling [27]. The LEPR and LEP-
$R O T$ transcripts share the first two exons, which are not translated in the LEPR gene [28]. Among the LEPR isoforms, the long form (LEPRb) is primarily expressed in specific nuclei of the hypothalamus, whereas the short isoform (LEPRa) is expressed in most tissues. These two isoforms of LEPR have identical extracellular domains but differ in the length of their intracellular domains, which contributes to their different capacity for signal transduction [29]. On the other hand, our CNV analyses of the Affymetrix SNP array 5.0 and QMPSF revealed a varied length of the $C N V$ region at the $L E P R$ gene locus. Also, we found that the E2 DNA copy numbers did not represent DNA copy numbers of the whole LEPR gene but only a partial sequence containing LEPROT gene. Thus, this finding suggests that E2 DNA copy numbers may negatively regulate LEPR gene expression through a gene dosage effect of $L E P R O T$.

However, LEPROT overexpression decreases only cell surface expression of LEPR without modifying the total amount of LEPR [30]. In our study, the observed weak correlation of E2 DNA copy numbers with LEPR mRNA levels in LCLs might be ascribed to inappropriate selection of target tissues for LEPR and LEPROT expression studies. Thus, the correlation of high E2 DNA copy number with LEPROT gene expression may be more significant in an appropriate LEPR target tissues such as the hypothalamus, pancreatic $\beta$-cells, or adipocytes. Elucidating tissue-specific regulation of LEPR gene expression could explain the complex pattern of association of phenotypes with the E2 DNA copy number variation. It remains to be investigated whether the E2 copy number confers a gene dosage effect of LEPROT on LEPR signaling using an appropriate target tissue, and whether this occurs via either transcriptional regulation or intracellular transport of LEPR. Alternatively, the E2 DNA sequence may merely play a role as a direct negative transcriptional regulatory sequence for the LEPR gene expression.

\section{Conclusion}

A prior CNV analysis of Affymetrix $50 \mathrm{~K} \mathrm{SNP}$ and 5.0 array chip data indicated the potential presence of $\mathrm{CNVs}$ at the LEPR gene locus as well as a varied length of the $\mathrm{CNV}$ region. DNA copy number measurements at the LEPR gene locus and subsequent association studies revealed that lower copy numbers of the E2 DNA sequence around LEPROT gene were associated with detrimental phenotypes of metabolic traits (e.g., higher fasting glucose and total cholesterol levels) as well as the risk of T2DM. In addition, the E2 DNA copy number exhibited a negative correlation with LEPR gene expression but a positive correlation with LEPROT gene expression. More research may be warranted to determine if LEPROT expression impacts LEPR expression. 
Table 2: The nested case-control study of T2DM

\begin{tabular}{|c|c|c|c|c|c|c|}
\hline \multirow[t]{2}{*}{ Case-control } & \multicolumn{3}{|c|}{ E2 DNA copy number groups } & \multirow[t]{2}{*}{ Odds ratio (OR) } & \multirow[t]{2}{*}{$\mathrm{Cl}(95 \%)$} & \multirow[t]{2}{*}{$P$ value* } \\
\hline & Low CN (1X) & High CN (2X) & Sum & & & \\
\hline T2DM case subjects $(n=135)$ & $86(63.7 \%)$ & $49(36.3 \%)$ & $135(100 \%)$ & 1.92 & $1.26 \sim 2.96$ & 0.003 \\
\hline non-T2DM control subjects $(n=258)$ & $123(47.7 \%)$ & $135(52.3 \%)$ & $258(100 \%)$ & & & \\
\hline Total $(n=393)$ & $209(53.2 \%)$ & $184(46.8 \%)$ & $393(100 \%)$ & & & \\
\hline
\end{tabular}

$P$ value*: Logistic regression analysis

\section{Methods}

\section{Study samples}

Subjects described in this study include 1,204 individuals from the Korean Genome and Epidemiology Study (KoGES) for CNV detection and subsequent association studies. The KoGES is a community-based prospective cohort study of chronic diseases (e.g., diabetes and hypertension) and their relationship with potential risk factors or lifestyles, which was started in 2001. The study design, sampling, concept and consent have been previously described [31,32]. Briefly, a total of 10,038 individuals participated in baseline examinations. Approximately $86.6 \%(n=8,693)$ and $67.8 \%(n=6,085)$ of the baseline study subjects participated in the first and the second 2year follow-up studies, respectively.

For the study of CNV association with metabolic traits, we randomly selected 1,067 non-diabetic subjects who did not develop T2DM during either baseline or two rounds of 2-year follow-up period from the KoGES. WHO criteria were used to define T2DM using an oral glucose tolerance test. Diabetes cases were defined as subjects who were determined to have T2DM at baseline,

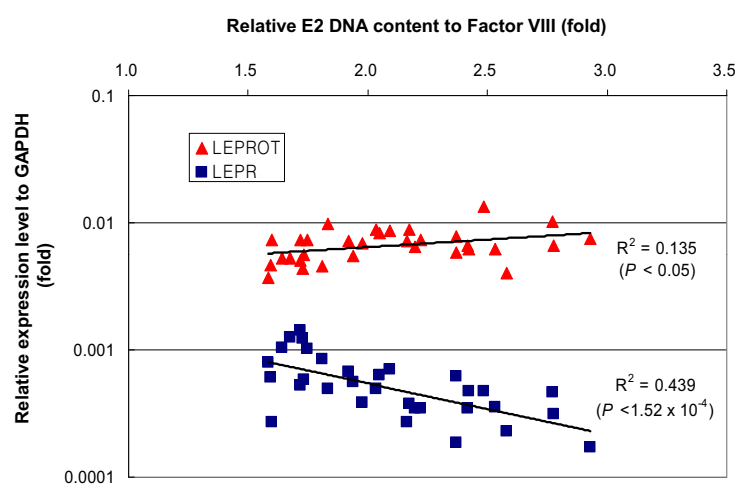

Figure 3 Correlation of the E2 DNA copy number with LEPR and LEPROT transcription levels. Expression levels of $L E P R$ and $L E P R O T$ relative to GAPDH were compared to the relative E2 DNA content in 32 strains of LCLs. Relative E2 DNA content was calculated from QMPSF data in relation to DNA content at the Factor VIII gene locus in LCLs. and then diabetes was diagnosed at least one time during two rounds of 2-year follow-ups. For the nested case-control study, T2DM cases $(n=137)$ were matched for sex, age \pm 1 , and $B M I \pm 0.1$, with control subjects $(\mathrm{n}=258)$ who did not have diabetes in either baseline or during the 2year follow-ups. This study was approved by the institutional review boards of Korea Centers for Disease Control and Prevention.

\section{DNA copy number measurement}

DNA samples used for DNA copy number measurement were provided by the National Biobank of Korea in Korea Centers for Disease Control and Prevention. We extracted CNV information for candidate genes (diabetes-and obesity-related) from the Affymetrix $50 \mathrm{~K} \mathrm{SNP}$ chip data in order to estimate whether CNVs were detectable within or near these genes in the Korean population. The Affymetrix $50 \mathrm{~K}$ SNP chip data was obtained from the Korean HapMap samples [33]. CNV analysis using CNAT3 (Affymetrix) indicated that the LEPR gene locus contained potential CNV regions (CNVRs) in this Korean population (Additional file 1) [34]. In addition, we selected a copy number invariant region (CN2-2) in chromosome 2 (2q36.1) that exhibited the least copy number variation of the CN2-2 locus among the 90 individuals tested (Additional file 4, 5).

A potential CNV-affected region near rs2025804, upstream of the long isoform of LEPR (LEPRb, NM_002303), was chosen for experimental detection of DNA copy numbers using the QMPSF method [35]. The QMPSF reaction included the Factor VIII gene and CN22 as references [34,36,37]. The relative copy numbers of a target locus were calculated in relation to the copy numbers of the Factor VIII gene or CN2-2. These two normalizing genes yielded almost same results when used for calculating relative copy numbers. All samples were subjected to three rounds of QMPSF reactions. All reactions were performed in duplicate.

For the justification of further CNV calling, DNA copy numbers of Factor VIII gene were compared between male and female subjects (Additional file 4). Based on the relative copy numbers of Factor VIII gene to $\mathrm{CN} 2-2$ 
region, individuals of lower or higher copy number groups were assigned to be $1 \mathrm{X}$ or $2 \mathrm{X}$ of DNA copy number for Factor VIII gene. The copy numbers (1X or $2 \mathrm{X}$ ) of Factor VIII gene was perfectly matched to individuals' sex.

Fluorescent primers were designed to target a specific region of the $L E P R$ gene locus, encompassing over $216 \mathrm{~kb}$ of chromosome 1p31, as well as the Factor VIII gene and CN2-2 loci used for normalization of the QMPSF reactions. Following optimization of the PCR reaction, multiplex PCR was performed with the appropriate primers (Additional file 6). The amplicon size for the LEPR locus was $242 \mathrm{bp}$ or $245 \mathrm{bp}$ depending on the presence of a trinucleotide deletion (-/AGG, rs60086513, at chromosomal position 65603354-65603358) and 199bp for the Factor VIII gene. The DNA copy number of the LEPR locus in relative to the Factor VIII reference was calculated according to the peak height measurements of target and reference loci. The histogram of the LEPR copy numbers indicates two subpopulations among the non-diabetes subjects who had either low or high copy numbers at the LEPR locus (Additional file 2). Thus, median values of the DNA copy number relative to Factor VIII in non-diabetic male and female groups were used as cutoff values to call DNA copy number values in male and female groups, respectively. Finally, either a 'low (1X)' or 'high (2X)' DNA copy number value at the $L E P R$ locus was assigned to all individuals.

\section{Quantitative real-time PCR}

Total RNA was isolated from EBV-transformed lymphoblastoid cell lines (LCLs) that were generated from peripheral blood mononuclear cells of participants. cDNA was synthesized as previously described [38] and then used in SYBR green PCR with the appropriate primers (Additional file 6). The difference in threshold cycles $(\mathrm{Ct})$ between $\mathrm{GAPDH}$ and the test genes was determined from three experiments, each performed in triplicate. The expression levels of the target genes were determined relative to the expression level of GAPDH.

\section{Statistical analyses}

All data are presented as mean \pm SD. Student's $t$ test was used to compare means of the baseline measurements between two groups. For statistical analysis, DNA copy numbers were dichotomized as ' 1 ' for low copy number and ' 2 ' for high copy number at the LEPR locus. Multiple regressions were performed for association analyses of metabolic phenotypes in non-diabetic subjects while adjusting for age and sex, which was then corrected by the Bonferroni method for multiple testing. Logistic regression analysis was used for calculating P-values, controlling for age, sex, and BMI as covariates. All analyses were performed with the SPSS 12.0 Statistical Software package.

\section{Additional material}

Additional file 1 Copy number variations at the LEPR locus in a Korean population. LEPR CNVs were analyzed using the Affymetrix $50 \mathrm{~K}$ SNP (A, B) and 5.0 SNP arrays (C) for 90 Korean individuals. (A) Affymetrix 50 K SNP array data was obtained from 90 individuals from the Korean HapMap project and then used to extract copy number information using the CNAT3 in reference to the Korean reference genome assembly of 90 individuals. For each SNP probe, standard deviation (STD) of the copy number (CN) values from 90 individuals was calculated and plotted along with the physical positions of SNP probes near the LEPR locus on chromosome 1. The STD of 0.25 was chosen as a cutoff value for CNV calling. A dashed box indicates copy number variations of the LEPR gene. (B) The Affymetrix $50 \mathrm{~K}$ SNP array data were analyzed to define CNV regions in reference to the Affymetrix reference genome assembly (provided by Affymetrix Inc.). The $P$ value of $<0.01$ was chosen to call CNVs. The CNV regions at the LEPR locus for 90 individuals were schematically depicted near the LEPR locus. A dashed box indicates copy number variations at the LEPR gene. Red bars: copy number gains, blue bars: copy number losses. (C) The whole genomes of 90 individuals were analyzed for CNV detection using the Affymetrix SNP array 5.0, and then compared with one specific reference genome (NA07357). The DNA-Chip Analyzer (dChip) was used for CNV detection http://www.dchip.org. dChip is a Windows software package for probelevel and high-level analysis of gene expression microarrays and SNP microarrays. dChip performed invariant set normalization on the 91 chip data (90 Koreans and one reference). Next it calculated model-based expression values. Copy number variations were inferred by applying median smoothing method. Only CNV regions covering LEPR gene were shown. Assuming that $\mathrm{CN}$ states are $2 \mathrm{~N}$ in the reference genome, $\mathrm{CN}$ states indicate the copy numbers of corresponding genomic locus for each individual.

Additional file 2 Histogram of the E2 DNA content among non-T2DM subjects. E2 DNA content was calculated relative to the DNA content at the Factor VIII gene locus from QMPSF data and then plotted to display the distribution pattern of E2 DNA copy numbers among the non-diabetes subjects. The median copy numbers in the men's and women's groups were used to divide them into two subpopulations of lower and higher E2 DNA copy number individuals. The E2 DNA content was then dichotomized into 'lower' or 'higher' copy number groups.

Additional file $\mathbf{3}$ Characteristics of case-control subjects. *: Student's t test for difference between low and high CN groups within either cases or controls. **: Student's t-test for difference between T2DM cases and nonT2DM controls.

Additional file 4 Justification of the QMPSF-based CNV calling using Factor VIII and CN2-2 references. A) Experimental validation of the CN2-2 copy number invariant region using QMPSF. CNV analysis of the Affymetrix 50 k SNP array data for 90 individuals identified copy number invariant regions with the least standard deviation of copy number $(\mathrm{CN})$ values in the CNAT3 analysis. Relative copy numbers of the CN2-2 region were calculated in relative to the Factor VIII gene reference from 35 individuals. Error bars indicate standard deviations from three independent QMPSF reactions. Each reaction was performed in duplicate. Relative copy numbers of CN2-2 region to Factor VIII gene exhibited $7.3 \%$ of coefficient of variation (CV), suggesting that CN2-2 can be used as a good internal control of further QMPSF reactions. B) Copy number distribution of Factor VIII gene in male and female subjects. Total individuals $(n=1,202)$ were clearly divided into two subgroups (male and female groups) by relative DNA copy numbers of Factor VIII gene to CN2-2 region. Individuals of lower or higher copy number groups were assigned to be $1 \mathrm{X}$ or $2 \mathrm{X}$ for Factor VIII gene. The DNA copy numbers (1X or $2 X)$ of Factor VIII gene were perfectly matched to individuals' sex.

Additional file $\mathbf{5}$ Copy number invariant regions. a: Copy number values (CN) of each SNP probe were obtained from CNV analysis of 90 individuals using the CNAT3. b: Average of copy number values of 90 individuals for each SNP probe. c: Standard deviation of copy number values of 90 individuals for each SNP probe. d: Average copy number values of all SNP probes for 90 individuals within the CNV region. e: Standard deviations of all probes for 90 individuals within the CNV region.

Additional file 6 Primers used in QMPSF and real-time PCR. 


\section{Abbreviations}

CNV: copy number variation; QMPSF: quantitative multiplex PCR of short fluorescent fragment; LCL: Iymphoblastoid cell line; LEPR: leptin receptor; T2DM: type 2 diabetes mellitus.

\section{Authors' contributions}

JPJ developed the concept and wrote the paper. JPJ and BGH designed the study. SMS generated and analyzed experimental data, and drafted the manuscript. HYN and EJH participated in the QMPSF experiment. GMR extracted and analyzed CNV information from the chip data. HLK and BGH helped with interpretation of the results. BGH supervised the project. All authors read and approved the final manuscript.

\section{Acknowledgements}

We would like to thank Dr. Joo-Young Lee for helpful advice during the statistical analysis. DNA samples for this study were provided by National Biobank of Korea. Epidemiological data used in this study were provided from the Korean Genome and Epidemiology Study, KoGES (2001-6111-221, 2002-6111-221). This work was supported by an intramural grant (2007-N-00353-00/2910-212207) from Korea National Institute of Health, Korea Centers for Disease Control and Prevention.

\section{Author Details}

'Division of Biobank for Health Sciences, Korea National Institute of Health, Korea Centers for Disease Control and Prevention, 194 Tongil Ro, Seoul, 122 701 , Korea and ${ }^{2}$ Center for Genome Science, Korea National Institute of Health, Korea Centers for Disease Control and Prevention, 194 Tongil Ro, Seoul, 122 701, Korea

Received: 24 August 2009 Accepted: 12 July 2010

Published: 12 July 2010

\section{References}

1. Aiston $S$, Agius L: Leptin enhances glycogen storage in hepatocytes by inhibition of phosphorylase and exerts an additive effect with insulin. Diabetes 1999, 48:15-20.

2. Wauters M, Considine RV, Van Gaal LF: Human leptin: from an adipocyte hormone to an endocrine mediator. Eur J Endocrinol 2000, 143:293-311.

3. Minokoshi Y, Kim YB, Peroni OD, Fryer LG, Müller C, Carling D, Kahn BB: Leptin stimulates fatty-acid oxidation by activating AMP-activated protein kinase. Nature 2002, 415:339-343.

4. Seufert J: Leptin effects on pancreatic beta-cell gene expression and function. Diabetes 2004, 53(Suppl 1):S152-8.

5. Clément K, Vaisse C, Lahlou N, Cabrol S, Pelloux V, Cassuto D, Gourmelen M, Dina C, Chambaz J, Lacorte JM, Basdevant A, Bougnères $P$, Lebouc $Y$, Froguel P, Guy-Grand BA: A mutation in the human leptin receptor gene causes obesity and pituitary dysfunction. Nature 1998, 392:398-401.

6. Farooqi IS, Wangensteen T, Collins S, Kimber W, Matarese G, Keogh JM, Lank E, Bottomley B, Lopez-Fernandez J, Ferraz-Amaro I, Dattani MT, Ercan O, Myhre AG, Retterstol L, Stanhope R, Edge JA, McKenzie S, Lessan N, Ghodsi M, De Rosa V, Perna F, Fontana S, Barroso I, Undlien DE, O'Rahilly S: Clinical and molecular genetic spectrum of congenital deficiency of the leptin receptor. N Engl J Med 2007, 356:237-247.

7. Chen $\mathrm{H}$, Charlat O, Tartaglia LA, Woolf EA, Weng X, Ellis SJ, Lakey ND, Culpepper J, Moore KJ, Breitbart RE, Duyk GM, Tepper RI, Morgenstern JP: Evidence that the diabetes gene encodes the leptin receptor: identification of a mutation in the leptin receptor gene in $\mathrm{db} / \mathrm{db}$ mice. Cell 1996, 84:491-495.

8. Lee GH, Proenca R, Montez JM, Carroll KM, Darvishzadeh JG, Lee Jl, Friedman JM: Abnormal splicing of the leptin receptor in diabetic mice. Nature 1996, 379:632-635.

9. Rosmond R, Chagnon YC, Holm G, Chagnon M, Pérusse L, Lindell K, Carlsson B, Bouchard C, Björntorp P: Hypertension in obesity and the leptin receptor gene locus. J Clin Endocrinol Metab 2000, 85:3126-3131

10. Takahashi-Yasuno A, Masuzaki H, Miyawaki T, Ogawa Y, Matsuoka N Hayashi T, Hosoda K, Inoue G, Yoshimasa Y, Nakao K: Leptin receptor polymorphism is associated with serum lipid levels and impairment of cholesterol lowering effect by simvastatin in Japanese men. Diabetes Res Clin Pract 2003, 62:169-175.
11. van Rossum CT, Hoebee B, van Baak MA, Mars M, Saris WH, Seidell JC: Genetic variation in the leptin receptor gene, leptin, and weight gain in young Dutch adults. Obes Res 2003, 11:377-386.

12. Loos RJ, Rankinen T, Chagnon Y, Tremblay A, Pérusse L, Bouchard C: Polymorphisms in the leptin and leptin receptor genes in relation to resting metabolic rate and respiratory quotient in the Québec Family Study. Int J Obes 2006, 30:183-190.

13. Park KS, Shin HD, Park BL, Cheong HS, Cho YM, Lee HK, Lee JY, Lee JK, Oh B, Kimm K: Polymorphisms in the leptin receptor (LEPR)--putative association with obesity and T2DM. J Hum Genet 2006, 51:85-91.

14. lafrate AJ, Feuk L, Rivera MN, Listewnik ML, Donahoe PK, Qi Y, Scherer SW Lee C: Detection of large-scale variation in the human genome. Nat Genet 2004, 36:949-951

15. Sebat J, Lakshmi B, Troge J, Alexander J, Young J, Lundin P, Månér S, Massa H, Walker M, Chi M, Navin N, Lucito R, Healy J, Hicks J, Ye K, Reiner A, Gilliam TC, Trask B, Patterson N, Zetterberg A, Wigler M: Large-scale copy number polymorphism in the human genome. Science 2004, 305:525-528.

16. Human Genome Structural Variation Working Group, Eichler EE, Nickerson DA, Altshuler D, Bowcock AM, Brooks LD, Carter NP, Church DM, Felsenfeld A, Guyer M, Lee C, Lupski JR, Mullikin JC, Pritchard JK, Sebat J, Sherry ST, Smith D, Valle D, Waterston RH: Completing the map of human genetic variation. Nature 2007, 447:161-165

17. Aitman TJ, Dong R, Vyse TJ, Norsworthy PJ, Johnson MD, Smith J, Mangion J, Roberton-Lowe C, Marshall AJ, Petretto E, Hodges MD, Bhangal G, Patel SG, Sheehan-Rooney K, Duda M, Cook PR, Evans DJ, Domin J, Flint J, Boyle $\mathrm{JJ}$, Pusey CD, Cook HT: Copy number polymorphism in Fcgr3 predisposes to glomerulonephritis in rats and humans. Nature 2006, 439:851-815.

18. Gonzalez E, Kulkarni H, Bolivar H, Mangano A, Sanchez R, Catano G, Nibbs RJ, Freedman Bl, Quinones MP, Bamshad MJ, Murthy KK, Rovin BH, Bradley W, Clark RA, Anderson SA, O'connell RJ, Agan BK, Ahuja SS, Bologna R, Sen L, Dolan MJ, Ahuja SK: The influence of CCL3L1 gene-containing segmental duplications on HIV-1/AIDS susceptibility. Science 2005, 307:1434-1440

19. Wilson GM, Flibotte S, Chopra V, Melnyk BL, Honer WG, Holt RA: DNA copy number analysis in bipolar disorder and schizophrenia reveals aberrations in genes involved in glutamate signaling. Hum Mol Genet 2006, 15:743-749.

20. Braude I, Vukovic B, Prasad M, Marrano P, Turley S, Barber D, Zielenska M, Squire JA: Large scale copy number variation (CNV) at $14 q 12$ is associated with the presence of genomic abnormalities in neoplasia. BMC Genomics 2006, 7:138.

21. Hollox EJ, Huffmeier U, Zeeuwen PL, Palla R, Lascorz J, Rodijk-Olthuis D, van de Kerkhof PC, Traupe H, de Jongh G, den Heijer M, Reis A, Armour JA, Schalkwijk J: Psoriasis is associated with increased beta-defensin genomic copy number. Nat Genet 2008, 40:23-25.

22. Blaskó B, Kolka R, Thorbjornsdottir P, Sigurdarson ST, Sigurdsson G, Rónai Z, Sasvári-Székely M, Bödvarsson S, Thorgeirsson G, Prohászka Z, Kovács M, Füst G, Arason GJ: Low complement C4B gene copy number predicts short-term mortality after acute myocardial infarction. Int Immunol 2007, 20:31-37.

23. Covey SD, Wideman RD, McDonald C, Unniappan S, Huynh F, Asadi A, Speck M, Webber T, Chua SC, Kieffer TJ: The pancreatic beta cell is a key site for mediating the effects of leptin on glucose homeostasis. Cell Metab 2006, 4:291-302.

24. Bingham NC, Anderson KK, Reuter AL, Stallings NR, Parker KL: Selective loss of leptin receptors in the ventromedial hypothalamic nucleus results in increased adiposity and a metabolic syndrome. Endocrinology 2008, 149:2138-2148.

25. McMinn JE, Liu SM, Liu H, Dragatsis I, Dietrich P, Ludwig T, Boozer CN, Chua SC Jr: Neuronal deletion of Lepr elicits diabesity in mice without affecting cold tolerance or fertility. Am J Physiol Endocrinol Metab 2005, 289:E403-411.

26. Huan JN, Li J, Han Y, Chen K, Wu N, Zhao AZ: Adipocyte-selective reduction of the leptin receptors induced by antisense RNA leads to increased adiposity, dyslipidemia, and insulin resistance. $J \mathrm{Biol}$ Chem 2003, 278:45638-45650

27. Baskin DG, Seeley RJ, Kuijper JL, Lok S, Weigle DS, Erickson JC, Palmiter RD, Schwartz MW: Increased expression of mRNA for the long form of the leptin receptor in the hypothalamus is associated with leptin hypersensitivity and fasting. Diabetes 1998, 47:538-543. 
28. Mercer JG, Moar KM, Hoggard N, Strosberg AD, Froguel P, Bailleul B: B219/ OB-R 5'-UTR and leptin receptor gene-related protein gene expression in mouse brain and placenta: tissue-specific leptin receptor promoter activity. J Neuroendocrinol 2000, 12:649-655

29. Ghilardi N, Ziegler S, Wiestner A, Stoffel R, Heim MH, Skoda RC: Defective STAT signaling by the leptin receptor in diabetic mice. Proc Nat Acad Sci 1996, 93:6231-6235.

30. Couturier C, Sarkis C, Séron K, Belouzard S, Chen P, Lenain A, Corset L, Dam J, Vauthier V, Dubart A, Mallet J, Froguel P, Rouillé Y, Jockers R: Silencing of OB-RGRP in mouse hypothalamic arcuate nucleus increases leptin receptor signaling and prevents diet-induced obesity. Pro Natl Acad Sci 2007, 104:19476-19481.

31. Shin C, Abbott RD, Lee H, Kim J, Kimm K: Prevalence and correlates of orthostatic hypotension in middle-aged men and women in Korea: the Korean Health and Genome Study. J Hum Hypertens 2004, 18:717-723.

32. Lim S, Jang HC, Lee HK, Kimm KC, Park C, Cho NH: The relationship between body fat and C-reactive protein in middle-aged Korean population. Atherosclerosis 2006, 184:171-177.

33. Kim KJ, Lee HJ, Park MH, Cha SH, Kim KS, Kim HT, Kimm K, Oh B, Lee JY: SNP identification, linkage disequilibrium, and haplotype analysis for a 200-kb genomic region in a Korean population. Genomics 2006 88:535-540

34. Jeon JP, Shim SM, Jung J, Nam HY, Oh B, Kimm K, Kim HL, Han BG: A Comprehensive Profile of DNA Copy Number Variations in a Korean Population: Identification of Copy Number Invariant Regions among Koreans. Exp Mol Med 2009, 41(9):618-628.

35. Vaurs-Barriere C, Bonnet-Dupeyron MN, Combes P, Gauthier-Barichard F, Reveles XT, Schiffmann R, Bertini E, Rodriguez D, Vago P, Armour JA, Saugier-Veber P, Frebourg T, Leach RJ, Boespflug-Tanguy O: Golli-MBP copy number analysis by FISH, QMPSF and MAPH in 195 patients with hypomyelinating leukodystrophies. Ann Hum Genet 2006, 70:66-77.

36. Levine RL, Wadleigh M, Cools J, Ebert BL, Wernig G, Huntly BJ, Boggon TJ, Wlodarska I, Clark JJ, Moore S, Adelsperger J, Koo S, Lee JC, Gabriel S, Mercher T, D'Andrea A, Frohling S, Dohner K, Marynen P, Vandenberghe P, Mesa RA, Tefferi A, Griffin JD, Eck MJ, Sellers WR, Meyerson M, Golub TR, Lee SJ, Gilliland DG: Activating mutation in the tyrosine kinase JAK2 in polycythemia vera, essential thrombocythemia, and myeloid metaplasia with myelofibrosis. Cancer Cell 2005, 7:387-397.

37. Jeon JP, Shim SM, Nam HY, Baik SY, Kim JW, Han BG: Copy number increase of 1 p36.33 and mitochondrial genome amplification in Epstein-Barr virus-transformed lymphoblastoid cell lines. Cancer Genet Cytogenet 2007, 173:122-130.

38. Baik SY, Yun HS, Lee HJ, Lee MH, Jung SE, Kim JW, Jeon JP, Shin YK, Rhee HS, Kimm KC, Han BG: Identification of stathmin 1 expression induced by Epstein-Barr virus in human B lymphocytes. Cell Prolif 2007, 40:268-281.

doi: 10.1186/1471-2164-11-426

Cite this article as: Jeon et al., Copy number variation at leptin receptor gene locus associated with metabolic traits and the risk of type 2 diabetes mellitus BMC Genomics 2010, 11:426

Submit your next manuscript to BioMed Central and take full advantage of:

- Convenient online submission

- Thorough peer review

- No space constraints or color figure charges

- Immediate publication on acceptance

- Inclusion in PubMed, CAS, Scopus and Google Scholar

- Research which is freely available for redistribution

Submit your manuscript at www.biomedcentral.com/submit
C Biomed Central 